MERCADOLOGIA 


\title{
THE INFLUENCES IN THE FIRM'S PURCHASING DECISIONS: AN EXPERIMENTAL STUDY
}

\author{
AS INFLUÊNCIAS NAS DECISÕES DE COMPRAS DAS EMPRESAS: \\ UM ESTUDO EXPERIMENTAL
}

Roger Augusto Luna

Fundação Getúlio Vargas

\author{
Data de submissão: 07 jun. 2017. Data de aprovação: \\ 27 dez. 2017. Sistema de avaliação: Double blind review. \\ Universidade FUMEC / FACE. Prof. Dr. Henrique Cordeiro \\ Martins. Prof. Dr. Cid Gonçalves Filho.
}

\section{ABSTRACT}

Although the topic of anxiety has been widely discussed in the areas of psychology and marketing, especially when analyzing consumer behavior, the subject is still little explored in the purchasing processes in the Operations Management (OM) area. In this sense, the study deals with the topic in an exploratory way. Thus, a $2 \times 2$ factorial experiment was performed to understand the emotional phenomenon in purchasing processes in high and low emotional involvement scenarios versus immediate time and distant time for the event. The results obtained by III respondents show that the emotional phenomenon does not interfere in the purchasing processes in the scenarios presented. However, a reassessment of the scenarios and new studies should be conducted to confirm the hypotheses presented in the study.

\section{KEYWORDS}

Anxiety. Purchasing. Emotional Involvement. Experimental Method. Operations Management. 


\section{RESUMO}

Embora o tema da ansiedade tenha sido amplamente discutido nas áreas de psicologia e marketing, especialmente quando se analisa o comportamento do consumidor, o assunto ainda é pouco abordado para os processos de compras da área de Gestão de Operações (OM). Nesse sentido, o estudo aborda o tema de forma exploratória. Assim, um experimento fatorial $2 \times 2$ foi realizado para entender o fenômeno emocional nos processos de compras em cenários de envolvimento emocional alto e baixo versus tempo imediato e tempo distante para o evento. Os resultados obtidos por I I I respondentes mostram que o fenômeno emocional não interfere nos processos de compras nos cenários apresentados. No entanto, uma reavaliação dos cenários e novos estudos deve ser conduzida para confirmar as hipóteses apresentadas no estudo.

\section{PALAVRAS-CHAVE}

Ansiedade. Compras. Envolvimento Emocional. Método Experimento. Gestão de Operações.

\section{INTRODUCTION}

The performance of a company's purchasing area always requires attention and dexterity on the part of the buyer, negotiations and even personal involvement is an inherent aspect of the work. In a situation where the buyer is faced with the need to make an important purchase and with little time to do so, the pressure involved can bring some anxiety to this moment.

The way in which emotions are controlled by people can usually be explained by the context of beliefs and values generated by the society in which they are embedded (PARKISON, 1995). Thus, emotion can also be considered a form of expression and communication among people. According to Rossi et al. (2004), "emotions came to be understood as important antecedents of satisfaction".

During a purchase pro cess, Richins (1997) analyzed the emotions of consum- ers, noting a varied repertoire of emotions, both positive and negative, where anxiety was directly linked to consumer concern.

Marketing studies an alyze the profile, habits, feelings and emotions of consumers, including the presence of other consumers nearby (AGUIAR; FARIAS, 20I5). On the other hand, researches in the area of Operations Management still lack studies related to the feelings involved in the purchasing process.

Although, just as there is a constant concern on the part of both business and academia in assessing customer satisfaction and trust, it is also important to encourage studies of untapped marketing emotions that can enable companies to enhance customer relations. In theoretical development, as is the case with anxiety. The high emotional involvement and the perception of the risk present in some types of purchases lead to a belief that the 
anxiety construct can be part of the purchase decision process.

Thus, this research sought to analyze the theme of anxiety in purchases in an exploratory way through the emotional involvement of the respondent and the time until the event occurs.

Based on the theoretical framework presented, the hypotheses about anxiety in the purchase and proximity to the event were elaborated. To test these hypotheses, we used the experimental methodology by scenarios. At the end, the results are presented and discussed, in addition to the final considerations.

\section{Theoretical Background}

This section will introduce the themes of anxiety, emotional involvement and time for the event, which supported the research in its phase of understanding the theme and as a theoretical basis for the analysis and discussion of the empirical data.

\section{Anxiety}

Studies related to emotion are usually viewed in the area of psychology and disseminated to other areas, mainly marketing, thus, in psychology, anxiety is defined as an emotional state characterized by feelings of insecurity, impending doom, and conscious experience of intense dislike (DORIN, I978; DORSCH; HÄCKE; STAPF, 200I; PIERON, 1966). Anxiety could be related to human behavior, such as emotions, motivation, and flexibility in problem solving.

Mansell et al. (1999) concluded that socially anxious individuals are overly concerned with the negative evaluation of others. Facial expressions are a potential source of information about a path in re- lation to the reaction of others in a social situation. Thus, in social interactions, analysis of negative or positive expressions is usually a response to something that another person has said or done (MANSELL et al., 1999), which may determine a positive or negative reaction to perception of this relationship. For example, if someone is waiting to be interviewed for a good job, they will probably have typical reactions to pre-occurrence anxiety, such as fiddling with their hands or shuffling their feet.

Wooten (2000), for example, observed that anxiety was directly related to the possibility of success, that is, the less the chance of success, the greater the anxiety, and added that one of the factors that highlight the effects that influence this probability is the degree of uncertainty of occurrence. People get anxious when they are highly motivated to produce a reaction they desire in the recipient or in others, but are unsure of success (WOOTEN, 2000). Thus, the greater this uncertainty, the greater will be the anxiety of the person who is involved in achieving his/her goals, in pleasing the other person in this communication.

In the analysis of social anxiety, it was interpreted as the emotional discomfort associated with the awareness of the perspective of other people's analysis of a person, as a social goal (DABHOLKAR; BAGOZZI, 2002, MAUSS;WILHELM; GROSS, 2004). In other words, social anxiety is the degree of discomfort felt by a person in the presence of others (ABE et al., 1996).

If anxiety is associated with the tendency to deliberate and often display some degree of indecision ( $A B E$ et al., 1996), one can infer that anxiety affects interpersonal communication. Thus, both seller and customer anxiety would be 
a negative emotion characterized by a sense of uncertainty and discomfort toward the other involved in the relationship, discouraging achievement of goals, and creating a defense mechanism when this is still possible. Consequently, at the time of the decision, it is likely that clients will be more (dis) satisfied, depending on the level of anxiety involved.

The involvement of the buyer in the negotiation, or even the decision about when to buy, will generate an anxiety in which the indecision can affect this process (ABE et al., 1996; WOOTEN, 2000). The search for the buyer's positive outcome in this research may affect the decision-making process if time pressure is also taken into account.

Anxiety could still be linked to the positive outcome of a goal that has not yet been achieved and could vary from person to person. Believing in the possibility of a future favorable outcome could also generate anxiety because of the uncertainty embedded in this unfulfilled future (LAZARUS, 1999). Thus, a positive result to be achieved (someone who likes to demonstrate that he or she has truly enjoyed the gift received, for example) can also be considered as a significant aspect of the consumer's emotional state.

The literature indicates that anxiety could be one of the negative emotions. In other words, anxiety acts as a barrier in the interpersonal communications of the client or even the salesperson. It could be related to the perception of the possibility of occurrence of the event, but the greater the possibility of a positive result for the occurrence, the less the anxiety. In addition, the anxiety could increase the perception of risk in the client's purchase.

\section{Emotional involvement vs. time for the event}

The act of buying something, often may not have close involvement between the parties, such as an online purchase or even a donation. As seen, in a relationship, anxiety can generate as much success as it does failure. This leads to understanding that the perception of risk in some purchases may generate some anxiety, which would influence the decision making process, depending on the situation in which the buyer is involved.

Thus, the following hypotheses can be elaborated:

$-\mathbf{H I}$ : Emotional involvement is related to purchase anxiety;

$-\mathbf{H 2}$ : The time constraint is related to purchase anxiety.

As seen in the literature, anxiety is also related to emotional involvement and time for the event, so hypothesis $\mathrm{H} 3$ can be established:

$-\mathbf{H 3}$ : When the emotional involvement is high and the time for the event is immediate, the anxiety with the purchase is high.

\section{Method}

For the purpose of identifying the anxiety construct in the purchasing decision in the two scenarios presented, that is, high and low emotional involvement of the staff with the purchase and time away close to the event, we adopted the methodological process of experimentation through vignettes, where Emotional Involvement and Time for Event were manipulated so that the participants in the experiment could respond with greater reality, according to the vignette presented. The manipulations are presented in Table I. 
TABLE 1 - Research Design

\begin{tabular}{c|c}
\hline Vignette & Involvement / Lead Time \\
\hline Vignette 1 & High / High \\
\hline Vignette 2 & High / Low \\
\hline Vignette 3 & Low / High \\
\hline Vignette 4 & Low / Low \\
\hline
\end{tabular}

Source: Authors (2016)

\section{Vignette}

\section{- Scenario}

The holidays are coming! However, there are also concerns about the gifts we need to buy, children's vacations, and work activities. At the end of the year, you have a lot to celebrate, since you are in a new job, having recently been hired by a company to work in the purchasing area.

For the operationalization of the experiment, the following vignettes were elaborated:

\section{- Vignette I:}

You have recently been hired by the purchasing area of a company that you have longed to work for. Straight away, in the first purchase, you are responsible for purchasing articles for the company employees' Christmas party. There is great expectation for the annual party.

This is your opportunity to demonstrate your problem-solving skills and provide a good party for your colleagues. So you think about the negotiations, where to obtain the goods/services, the delivery arrangements, etc.

The party is the next day and you only have until the end of the day to make all the purchases.

\section{- Vignette 2:}

You have recently been hired by the purchasing area of a firm you have longed to work for. In the very first purchase, you are responsible for purchasing articles for the staff's xmas party. There is great expectation surrounding this annual party.
This is your opportunity to demonstrate your problem-solving skills and provide a good party for your fellows. So you think about the negotiations, where to acquire the items, the delivery details, etc.

The party will be in the next month and you have 30 days to complete all the purchases.

\section{- Vignette 3:}

In the club near your home, there will be a holiday party for the neighborhood. There will also be an opportunity to donate new toys, which will be passed on to a charity.

Donations are not mandatory and you only have until the following day to buy a toy.

\section{- Vignette 4:}

In the club near your home there will be a neighborhood holiday party. There will also be an opportunity to donate new toys, which will be transferred to a charity.

Donations are not required, and you still have 30 days to purchase a toy.

\section{Data Collection}

For measurement in this study of the dependent variable, anxiety, scales were created aimed at measuring the construct, anxiety in purchases.

In the proposed scenarios, the respondents should answer the statements that follow according to Table 2. Questions were also included to avoid bias in the research, as proposed by Hair Jr. et al. (2005), which will serve as a source of analysis as well. 
TABLE 2 - Question

\begin{tabular}{|c|c|c|}
\hline Dimension & Name & Cod_Dimen \\
\hline $\begin{array}{l}\text { Emotional Involve- } \\
\text { ment }\end{array}$ & I like the feeling of how best to buy for people & Env_EM1 \\
\hline $\begin{array}{l}\text { Emotional Involve- } \\
\text { ment }\end{array}$ & I always do a good job & Env_EM2 \\
\hline $\begin{array}{l}\text { Emotional Involve- } \\
\text { ment }\end{array}$ & I'm sure not to be frowned upon by my attitudes & Env_EM3 \\
\hline $\begin{array}{l}\text { Emotional Involve- } \\
\text { ment }\end{array}$ & I do not like to buy objects for other people & Env_EM4 \\
\hline $\begin{array}{l}\text { Emotional Involve- } \\
\text { ment }\end{array}$ & I feel confident when l'm shopping & Env_EM5 \\
\hline Anxiety & I get tense the moment people get the items I bought & Ansdd1 \\
\hline Anxiety & I'm worried about not being able to meet the expectations & Ansdd2 \\
\hline Anxiety & During the purchase I am thinking about the consequences of a wrong purchase & Ansdd3 \\
\hline Anxiety & I fear that people will judge me negatively by my actions & Ansdd4 \\
\hline Common Method Bias & You have time to make purchases & CMB1 \\
\hline Common Method Bias & My friends and family admire the company in which I work & CMB2 \\
\hline Common Method Bias & I have the habit of getting to know the product physically before acquiring it & CMB3 \\
\hline Event Date & I always anticipate when making purchases & Dat_Eve1 \\
\hline Event Date & I often prepare a schedule for my shopping activities & Dat_Eve2 \\
\hline Event Date & I stop buying from certain suppliers due to delivery delays & Dat_Eve3 \\
\hline Demographics & What is your household income? & Demo1 \\
\hline Demographics & Gender? & Demo2 \\
\hline Demographics & What is your age? & Demo3 \\
\hline Demographics & What is your background? & Demo4 \\
\hline Demographics & What is your occupation? & Demo5 \\
\hline
\end{tabular}

Source: Authors (2016)

Respondents were invited via e-mail to participate in the experiment, and instructed that they should read the scenario indicated by the Qualtrics website. After the data collection was completed, they were imported into the MS-Excel 2010 system, so that the database adjustment procedure could be performed.

Subsequently, the data were loaded into the Rcomander software, version 3.3.I for the statistical analyses.

\section{Dependent Variable}

To operationalize the dependent variable, anxiety, we used the Involvement and Time constructs for the event. The questions were directed so that respondents, after reading the scenario, responded according to their level of agreement on a 5-point Likert scale.

Emotional Involvement Scale (Env_EMI + Env_EM2 + Env_EM3 + Env_EM5), which generated a reasonable index of reliability, its Cronbach alpha being $\alpha=0.52$. Some scale items were removed so that there was a better result for this index.

Event Time Scale (Dat_Evel + Dat_Eve2 + Dat_Eve3) generated a good reliability index, its Cronbach alpha being $\alpha=0.62$. On this scale all items were kept.

\section{Manipulation Check}

After reading the vignettes, which were 
presented randomly through the Qualtrics website, the respondents started to respond to the questionnaire. In the questionnaire were used 5-point Likert scales with answers ranging from "totally disagree" to "totally agree". From this distribution of scenarios, one can calculate the statistical averages of each scenario.

\section{Results}

In this section the results of the $2 \times 2$ experiment will be presented.All analyzes will be done with dependent variable anxiety on purchases. For this study, a total of I I I valid questionnaires were considered.

\section{Descriptive Statistics of Results}

In the description of the results, a greater number of respondents were sought, and they covered a representative profile for the sample. To guarantee the randomness of the responses, demographic data ranges were created, resulting in a variation in the profiles of the respondents, as presented in Table 3.
In order to guarantee the randomness of the scenarios presented to the respondents, the Qualtrics website offers the function of randomizing the scenarios. According to Table 4, we can observe this situation of equilibrium among them, based on Hair Jr. et al., (2005), which suggests a minimum of 20 observations per cell.

In the distribution of the averages for the variables of high / low emotional involvement (Vignettes I and 2) time for the event far / near (Vignettes 3 and 4), one can notice in Table 5 a very low variation between the scenarios.

In order to identify if the distribution was normal, a statistical test of normality, the Shapiro-Wilk test, was performed, in which the p-value $>0.01$ was identified, according to Table 5, with which the Boxplot graphs of each vignette were created for best view, according to Figure I.

Each graph represents a quadrant between the low-involvement, long-time scenarios for the event and the scenario

TABLE 3 - Demographic Data

\begin{tabular}{l|c|c|c|c|c}
\hline \multicolumn{1}{c|}{ GENDER } & N & AGE & N & HOUSEHOLD INCOME (R\$) & N \\
\hline Man & 49 & up to 20 & 3 & up to 1,760 & 12 \\
\hline \multirow{2}{*}{ Woman } & & $21-30$ & 28 & $1,761-4,400$ & 20 \\
\hline & & $31-40$ & 50 & $4,401-6,160$ & 16 \\
\hline & & $41-50$ & 21 & $6,160-7,040$ & 7 \\
\hline & & over 51 & 9 & $7,041-8,800$ & 4 \\
\hline
\end{tabular}

Source: Authors (2016)

TABLE 4 - Answer by vignette

\begin{tabular}{c|c}
\hline VIGNETTE & N \\
\hline Vignette 1 & 30 \\
\hline Vignette 2 & 27 \\
\hline Vignette 3 & 25 \\
\hline Vignette 4 & 29 \\
\hline
\end{tabular}

Source: Authors (2016) 
TABLE 5 - Descriptive Statistics of Experimental Treatments

\begin{tabular}{|c|c|c|c|c|c|}
\hline VIGNETTE & MANIPULATION & MEAN & SD & p-value & $\mathbf{N}$ \\
\hline \multirow{3}{*}{ Vignette 1} & TOTAL & 2.41 & 0.52 & $p>0.01$ & \multirow{3}{*}{30} \\
\hline & Involv. High & 2.13 & 0.42 & $p>0.01$ & \\
\hline & Lead Time High & 2.68 & 0.87 & $p>0.01$ & \\
\hline \multirow{3}{*}{ Vignette 2} & TOTAL & 2.4 & 0.54 & $p>0.01$ & \multirow{3}{*}{27} \\
\hline & Involv. High & 2.77 & 0.63 & $p>0.01$ & \\
\hline & Lead Time Low & 2.53 & 0.74 & $p>0.01$ & \\
\hline \multirow{3}{*}{ Vignette 3} & TOTAL & 2.31 & 0.43 & $p>0.01$ & \multirow{3}{*}{25} \\
\hline & Involv. Low & 2.32 & 0.47 & $p>0.01$ & \\
\hline & Lead Time High & 2.31 & 0.64 & $p>0.01$ & \\
\hline \multirow{3}{*}{ Vignette 4} & TOTAL & 2.56 & 0.42 & $p>0.01$ & \multirow{3}{*}{29} \\
\hline & Involv. Low & 2.22 & 0.47 & $p>0.01$ & \\
\hline & Lead Time Low & 2.89 & 0,68 & $p>0.01$ & \\
\hline
\end{tabular}

Source: Authors (2016)

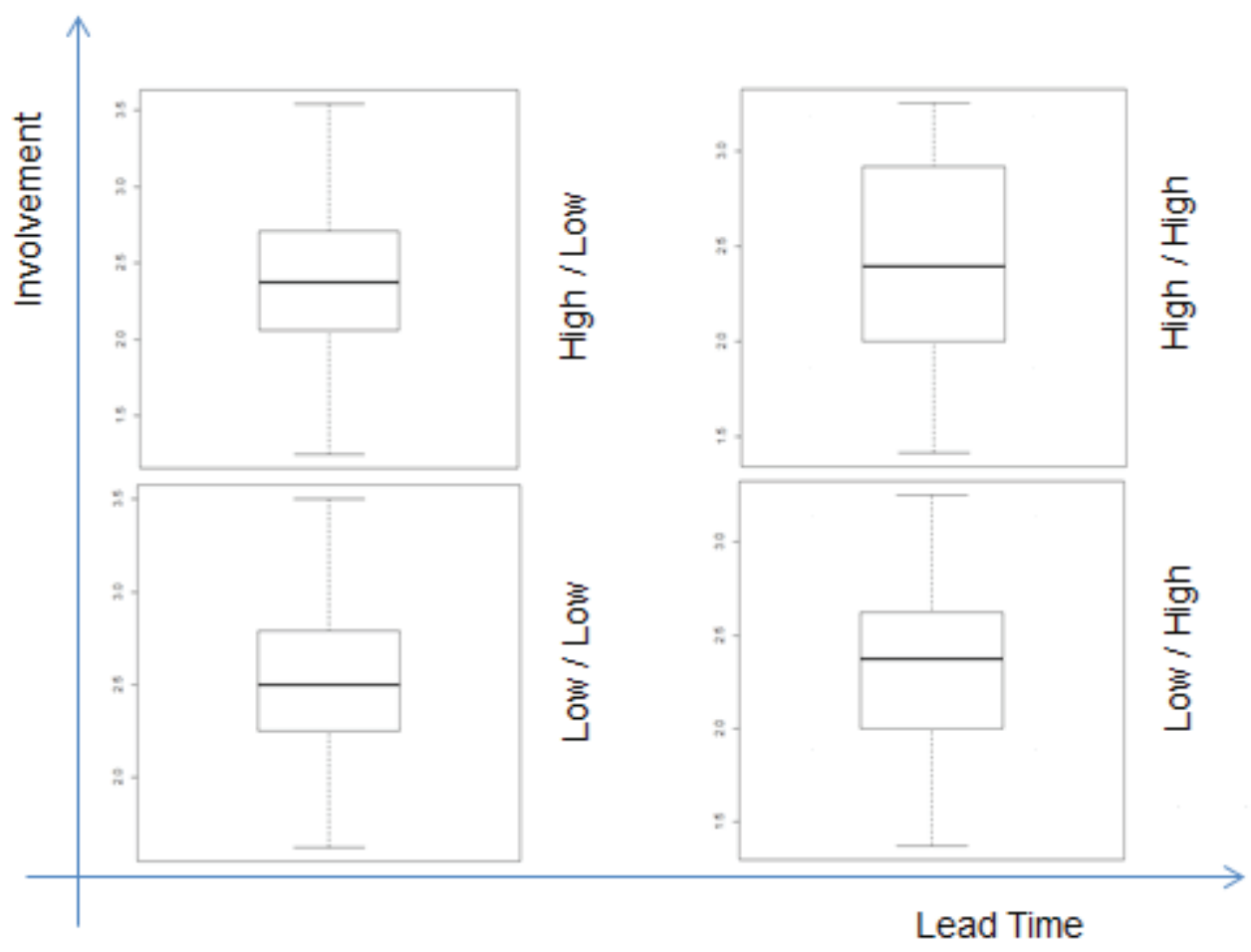

FIGURE 1 - Boxplot of the distribution of the data generated in each vignette

Source: Authors (2016)

where there was high involvement and little time for the event, thus allowing understanding of the scenarios. However, as seen in the graphs, the little variation among the proposed scenarios represents the little understanding of the respondents about the manipulations performed.

In addition, in view of the analyses carried out, it is necessary to establish new statistical analysis methodologies for the 
validation or rejection of the hypotheses proposed in this study.

\section{Discussion and Conclusion}

In view of the proposed objective of exploratory analysis of the anxiety issue in purchases through the emotional involvement of the respondent and the time until the event occurs, we sought to understand this phenomenon through a scenario-based experimental methodology.

Previous studies in the marketing field clearly show a proportionality of increased or decreased anxiety as the event approaches. This fact still needs future studies for confirmation in the Operations Management area given the proposed scenario.

For the results presented, it is noted that there is heterogeneity among the respondents, which guarantees a correct sample to develop research (HAIR Jr. et al., 2005).

The dependent variable, anxiety was manipulated in order to try to obtain different answers and interactions given by the respondents, as established by Sekaran et al. (2000), where the variable can have different values at different times. However, according to the results presented, it can be observed that there was no great variation among the proposed scenarios.

According to the Boxplot graphic presented, the data dispersion does not determine this variation, thus supporting the possibility that the respondents could not identify variation among the scenarios, and that the manipulations were not adequate.

Given this lack of identification of manipulation of the scenarios, reissue is necessary, since scenarios I and 2 argued about the purchase of items for a company party, while scenarios 3 and 4 argued about buying a gift for donation. Therefore, the four scenarios should keep the same argument and only perform the manipulations among the time for the event, involvement, priority and relevance.

Construction of the concept must be clear and rigorous. Considering this importance (HAIR Jr. et al. 2005), Sekaran et al. (2000) admit the existence of measurement of certain objects, in this case, anxiety, for which an ordinal scale was created, according to Table 2, to collect data from the proposed scenarios.

Profound studies on the topic can collaborate with firms to review their bargaining strategies on purchases and even the behavior of their employees in situations with high levels of tension.

The limitations of the method, for example, generalization may be an obstacle to replication, since it is difficult to replicate the conditions under which the experiment was applied, thus generating some bias. It is also worth mentioning the sample used. Despite the diversity of the respondents in this study, only individuals who had access to the Internet were questioned, since the research was made available in a virtual environment. 


\section{REFERÊNCIAS}

ABE, S.; BAGOZZI, R. P.; SADARANGANI, P. An investigation of construct validity and generalizability of the self-concept: self-consciousness in Japan and the United States. Journal of International Consumer Marketing, v. 8, n. 3, p. 97-I23, 1996.

AGUIAR, E. C.; FARIAS S. A. A percepção da presença dos outros consumidores e sua relação com emoções e valor hedônico de compra. Revista de Administração de Empresas - RAE. v. 55, n. 6, p. 7I 2 -723, 2015.

DABHOLKAR, P.; BAGOZZI, R. P. An attitudinal model of technology-based self-service: modeling effects of consumer traits and situational. Journal of the Academy of Marketing Science, v. 30, n.3, p. I84-20I, 2002

DORIN, E. Dicionário de psicologia: abrangendo terminologia de ciências correlatas. São
Paulo: Melhoramentos, 1978.

DORSCH, F.; HÄCKER, H.; STAPF, K. $H$. Dicionário de psicologia. Editora Vozes, 200I.

HAIR JR., J. F.; BABIN, B. J.; MONEY,A. H.; SAMOUEL, P. Fundamentos de Métodos de Pesquisa em Administração. Porto Alegre: Bookman, 2005

MANSELL,W.; CLARK,D.M.;EHLERS, A.; CHEN,Y-P.Social anxiety and attention away from emotional faces; Cognition and Emotion. v. 13 n. 6, p. 673-690, 1999.

MAUSS, I. B.;WILHELM, F. H.; GROSS, J. J. Is there less to social anxiety than meets the eyes? Emotion experience, expression, and bodily responding. Cognition and Emotion. v.18, n. 5, p. 631-662, 2004.

PARKINSON, B. Ideas and realities of emotion. London: Routledge, 1995.

PIERON, H. Dicionário de psicolo- gia. Rio de Janeiro: Globo, 1966.

QUALTRICS. www.qualtrics.com - research link: https://qtrial20 I 6q4azl.azl.qualtrics.com/ SE/?SID=SV_2ft5PzWDQIhw7qd RICHINS, M. L. Measuring Emotions in the Consumption Experience. Journal of Consumer Research, v. 24, p. 127-|46, 1997.

ROSSI, C.A.V.; LUCE, F. B.; MAZZON, J. A.; SLONGO, L. A. Solução Clássica para um Problema Contemporâneo: a Relevância da Satisfação de Clientes para Segmentar Mercados na Telefonia Brasileira Pós-Privatizações. In: ENCONTRO NACIONAL DOS PROGRAMAS DE PÓS-GRADUAÇÃO EM ADMINISTRAÇÃO, 28., 2004, Curitiba. Anais... Curitiba:Anpad, 2004.

SEKARAN, U. Research methods for business: a skill-building approach. 3. ed. New York: John Wiley, 2000. 